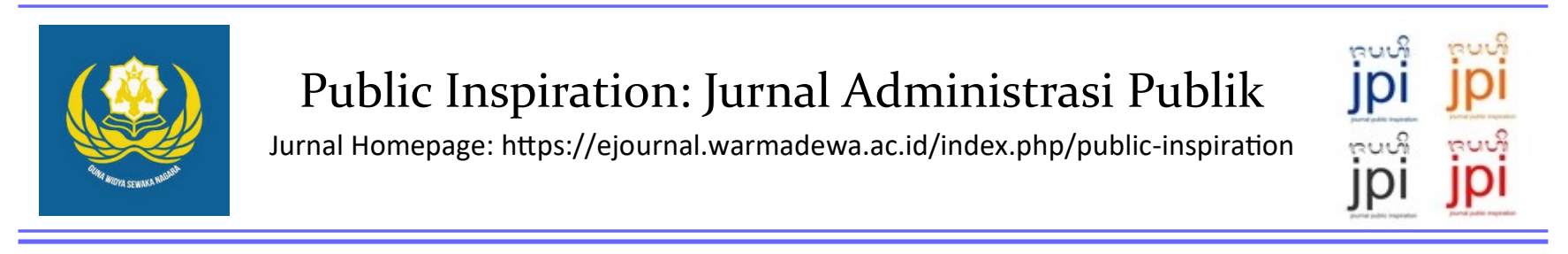

\title{
Penerapan Elektronik Kinerja (E-Kinerja) terhadap Motivasi Kerja Pegawai di Kantor Camat Klungkung
}

\author{
I Wayan Iwan Indrawan \\ Magister Administrasi Publik, Universitas Warmadewa, Denpasar, Bali-Indonesia \\ Corespondence Email: iwanindrawan@gmail.com
}

How to Cite: Indrawan, I. W. I. (2021). Penerapan Elektronik Kinerja (E-Kinerja) terhadap Motivasi Kerja Pegawai di Kantor Camat Klungkung. Public Inspiration: Jurnal Administrasi Publik, 6(1). 55-65. DOI: https://doi.org/10.22225/pi.6.1.2021.55-65

\begin{abstract}
One of policy applied by the Regional Governmeent of Klungkung Regency in order to encourage its employee's prosperity and motivation to increase their work and service quality is by giving regional working incentive through The Regent of Klungkung's regulation number 2 of 2019 which is later being implemented in Electronic Working System. And this system applicable in all Regional Organization Working system in Klungkung regency including those in the Kecamatan Klungkung office. According to that background the conclusion of the problem is how the implementation of the electronic working system toward employee's work motivation in The Kecamatan (a government system under the Regency) Klungkung Office. Is there any obstacles or supporting agent in the implementation of the system. To solve those problems certain method will be applied such as a qualitative method by holding an interview to employees in Klungkung Camat Office and observing directly the implementation of E-Working system at the office. The result of the observation comes to conclusion that the implementation of E-working has succeed in increasing employee's working motivation in the Camat Klungkung Office. There are some supporting facts and obstacles in the system implementation to motivate spirit of the employee. Those factors which is considered as a supporting facts are 1. A clear standard and objectives of the policy 2. Resources such as Human resources, budget and a proper equipment 3.The characteristic of Executor resources 4. A good communication between organizations 5. Disposition or obedience executor' attitude. While the factors which consider as an obstacles of this E-Working System is social, politic and economic situation.
\end{abstract}

Keywords: Working, E-working system; Work Motivation; Supporting factors; Problems and obstacles

\begin{abstract}
Abstrak
Kebijakan Pemerintah Kabupaten Klungkung untuk meningkatkan kesejahteraan pegawai, motivasi kerja, kinerja pegawai dan mutu pelayanan adalah dengan memberikan tunjangan kinerja daerah. Peraturan Bupati Klungkung Nomor 2 Tahun 2019 diimplementasikan dengan sistem Elektronik Kinerja (E-Kinerja) yang berlaku bagi semua Organisasi Perangkat Daerah (OPD) di Kabupaten Klungkung, termasuk juga di Kantor Camat Klungkung. Penelitian ini berupaya mengkaji penerapan E-Kinerja hubungannya dengan motivasi kerja pegawai. Masalah yang diangkat adalah penerapan Elektronik kinerja (E-Kinerja) terhadap motivasi kerja pegawai di Kantor Camat Klungkung, dan faktor-faktor pendukung serta penghambatnya Untuk memecahkan permasalahan tersebut dipergunakan metode kualitatif dengan cara melakukan wawancara kepada pegawai dan melihat langsung penerapan E-Kinerja di Kantor Camat Klungkung. Hasil penelitian menunjukkan bahwa penerapan system E-Kinerja mampu meningkatkan motivasi kerja pegawai di Kantor Camat Klungkung. Faktor pendukung meliputi: (1) Standar dan sasaran kebijakan yang jelas, (2) sumber daya meliputi SDM, dana, dan peralatan yang memadai, (3) Karakteristik organisasi pelaksana, (4) Komunikasi Antar Organisasi yang berjalan lancar, (5) Disposisi atau sikap para pelaksana yang taat aturan. Faktor penghambat E-Kinerja adalah lingkungan sosial, politik dan ekonomi.
\end{abstract}

Kata kunci: E-Kinerja; Motivasi kerja; Faktor pendukung; Masalah dan penghambat 


\section{Pendahuluan}

Dalam rangka mewujudkan good governance, pemerintah memberikan tunjangan berbasis kinerja kepada setiap ASN. Pemerintah Kabupaten Klungkung selalu berupaya untuk menciptakan pemerintahan yang baik. Salah satunya adalah dengan memberikan berbagai tunjangan kepada para pegawai sebagai upaya untuk memotivasi semangat kerja pegawai. Sejak Tahun 2019, pemberian tunjangan kinerja kepada ASN di Kabupaten Klungkung berdasarkan pada Peraturan Bupati Klungkung Nomor 2 Tahun 2019 yang kemudian di implementasikan dengan Elektronik Kinerja (EKinerja) dimana pemberian tunjangan kinerja berdasarkan pada jumlah kegiatan yang dilaporkan dalam sistem Elektronik Kinerja (E-Kinerja).

Namun apakah dengan pemberian tunjangan kinerja itu mampu meningkatkan motivasi kerja pegawai? Menurut (Mahendra, 2016) menyatakan bahwa pemberian tunjangan kinerja daerah kurang efektif dalam meningkatkan kinerja pegawai dan kurang efektif dalam memotivasi pelaksanaan tugas pokok dan fungsi pada Biro Perlengkapan dan Aset Daerah. Hasil yang sama juga di peroleh dalam penelitian yang dilakukan oleh (Hanifah, 2017) yang menyatakan bahwa tunjangan kinerja tidak berpengaruh terhadap motivasi kerja, tidak berpengaruh terhadap disiplin kerja pegawai. Sedangkan menurut (Putri, 2016), (Wuaten, 2013), (Usmiar, 2016), (Hardani, Bachri \& Dahniar, 2016), (Saleh \& Darwis, 2015) mengatakan bahwa pemberian tunjangan kinerja berpengaruh terhadap motivasi, disiplin dan kinerja pegawai.

Berdasarkan permasalahan tersebut penulis akan meneliti tentang Penerapan Elektronik Kinerja (E-Kinerja) Terhadap Motivasi Kerja Pegawai di Kantor Camat Klungkung

Adapun permasalahan yang akan diteliti dalam penelitian ini adalah

- Bagaimana penerapan Elektronik kinerja (E-Kinerja) terhadap motivasi kerja pegawai di Kantor Camat Klungkung?

- Apa faktor-faktor pendukung dan penghambat penerapan Elektronik kinerja (E-Kinerja) di Kantor Camat Klungkung?

Untuk menjawab kedua permasalahan tersebut, peneliti akan menggunakan Teori harapan oleh V. Vroom dan teori dan teori implementasi kebijakan publik dari Van Meter \& Van Hoorn.

Terdapat 3 konsep dalam Teori Harapan Vroom, yaitu:

- Harapan (Expectancy), yaitu kepercayaan seseorang bahwa suatu usaha akan menghasilkan kinerja tertentu. Effort (Usaha) $\rightarrow$ Performance (Kinerja).

- Instrumentality, yaitu kepercayaan seseorang bahwa suatu kinerja akan mendapatkan hasil tertentu. Performance (Kinerja) $\rightarrow$ Outcome (Hasil)

- Valensi yaitu akibat dari perilaku tertentu mempunyai nilai / martabat tertentu (daya/nilai motivasi) bagi setiap individu yang bersangkutan.

Kedua, Teori implementasi kebijakan yang dirumuskan Van Meter dan Van Horn disebut dengan A Model of the Policy Implementation (1975). Proses implementasi ini merupakan sebuah abstraksi atau performansi suatu kebijakan yang pada dasarnya secara sengaja dilakukan untuk meraih kinerja implementasi kebijakan yang tinggi yang berlangsung dalam hubungan berbagai variable yaitu

- Standar dan sasaran kebijakan

- Sumber daya

- Karakteristik organisasi pelaksana

- Komunikasi antar organisasi 
- Disposisi atau sikap para pelaksana

- Lingkungan sosial, politik, dan ekonomi

\section{Kebijakan Publik}

Dye (Agustino, 2008) mendefinisikan kebijakan publik merupakan upaya yang dipilih oleh pemerintah untuk dilakukan atau tidak dilakukan yang berupa sasaran atau tujuan program-program pemerintah. Sedangkan menurut Friedrick (Agustino, 2008), kebijakan publik sebagai serangkaian tindakan yang diusulkan seseorang, kelompok atau pemerintah dalam suatu lingkungan tertentu, dengan ancaman dan peluang yang ada. Kebijakan yang diusulkan tersebut ditujukan untuk memanfaatkan potensi sekaligus mengatasi hambatan yang ada dalam rangka mencapai tujuan tertentu.

Kebijakan dapat dipandang sebagai sebuah usaha untuk mencapai tujuan-tujuan tertentu, sekaligus sebagai upaya pemecahan masalah tertentu dengan menggunakan sarana-sarana tertentu, dan dalam waktu tertentu. Kebijakan umumnya bersifat mendasar karena kebijakan hanya menggariskan pedoman umum sebagai landasan bertindak dalam usaha mencapai tujuan yang telah ditetapkan.

Dengan demikian, kebijakan publik dapat dipahami sebagai kebijakan yang dibuat pemerintah, berorientasi kepada kesejahteraan dan peningkatan kinerja pegawai, yang diwujudkan dalam bentuk peraturan perundang-undangan. Kebijakan publik mempunyai sifat mengikat dan harus dipatuhi oleh seluruh anggota masyarakat tanpa terkecuali

Dalam konteks penelitian yang akan dilakukan, maka pengertian kinerja adalah tingkat kemampuan pencapaian hasil kerja yang dilakukan oleh pegawai di Kantor Camat Klungkung Kabupaten Klungkung dalam melaksanakan tugas pokok dan fungsinya

\section{Implementasi Kebijakan Publik}

Menurut Van Meter Van Horn (Agustino, 2008) menyatakan, "implementasi kebijakan adalah tindakan-tindakan yang dilakukan oleh individu, kelompok, pemerintah dan swasta yang diarahkan pada pencapaian tujuan dan sasaran yang telah ditetapkan" Implementasi kebijakan menyangkut tiga hal, yaitu:

1. Adanya tujuan atau sasaran kebijakan.

2. Adanya aktivitas atau kegiatan pencapaian tujuan.

3. Adanya hasil kegiatan.

\section{Pengertian Kinerja}

(Mangkunegara, 2011) mengemukakan kinerja sebagai berikut: Kinerja berasal dari kata job performance atau actual performance, yaitu hasil kerja secara kualitas dan kuantitas yang dicapai oleh seorang pegawai dalam melaksanakan tugasnya sesuai dengan tanggung jawab yang diberikan kepadanya. Ada tiga aspek yang saling berkaitan perlu dipahami setiap pegawai atau pimpinan suatu unit kerja atau organisasi yaitu;

1. Tugas atau pekerjaan yang menjadi tanggung jawabnya jelas,

2. Hasil yang diharapkan dari suatu pekerjaan atau fungsi menjadi jelas.

3. Waktu yang diperlukan menyelesaikan suatu pekerjaan tepat agar hasil yang diharapkan dapat terwujud.

\section{Tunjangan Kinerja}

(Sastrohadiwiryo, 2005), mengartikan sebagai imbalan jasa atau balas jasa yang diberikan oleh 
Public Inspiration: Jurnal Administrasi Publik, 6 (1) (2021), 58

Penerapan Elektronik Kinerja (E-Kinerja) terhadap Motivasi Kerja Pegawai di Kantor Camat Klungkung

instansi kepada para tenaga kerja karena tenaga kerja tersebut telah memberikan sumbangan tenaga dan pikiran demi kemajuan instansi guna mencapai tujuan yang telah ditetapkan.

\section{Metode}

Dalam penelitian ini menggunakan pendekatan deskriptif kualitatif. Pendekatan deskriptif kualitatif dalam penelitian ini untuk memberikan gambaran tentang Penerapan Elektronik kinerja (EKinerja) Terhadap Motivasi Kerja pegawai di Kantor Camat Klungkung Kabupaten Klungkung, dan merinci faktor pendukung serta kendala yang dihadapi.

Dalam penelitian ini menggunakan tehnik wawancara dan observasi dan pengamatan secara langsung mengenai penerapan E-Kinerja. Adapun penentuan informan dilakukan secara purposive random sampling. Adapun informan yang akan diwawancara adalah Camat, Sekretaris Camat, Kepala Seksi, Kepala Sub Bagian dan staf pada masing-masing Seksi dan Sub Bagian yang ditentukan berdasarkan masa kerja terlama.

\section{Elektronik Kinerja (E-Kinerja)}

Di Kabupaten Klungkung melalui Peraturan Bupati klungkung Nomor 2 Tahun 2019 Tentang Pemberian Tunjangan Kinerja Daerah Kepada Pegawai Negeri Sipil Dan Calon Pegawai Negeri sipil, mulai tanggal 1 januari 2019 diterapkan Elektonik tunjangan kinerja (E-Kinerja). Di mana sistem pembayaran tunjangan di sesuaikan dengan tugas / pekerjaan yang diselesaikan dan di laporkan. Artinya semakin banyak pekerjaan yang dikerjakan / diselesaikan dan dilaporkan, maka semakin besar pula tunjangan kerja yang diperoleh.

Sesuai dengan ketentuan Bab III Peraturan Bupati Klungkung Nomor 2 tahun 2019, tunjangan kinerja daerah terdiri atas 2 (dua) komponen, yaitu

Tunjangan Statis, diberikan berdasarkan pada nilai jabatan yang dihasilkan melalui proses evaluasi jabatan yang telah mendapatkan rekomendasi dari Kementerian Pendayagunaan Aparatur Negara dan Reformasi Birokrasi Republik Indonesia

Tunjangan Dinamis, diberikan berdasarkan pada aktivitas yang dilaporkan oleh masing-masing pegawai pada aplikasi E-Kinerja

Elektonik kinerja (E-Kinerja) merupakan aplikasi berbasis internet dan android yang digunakan oleh Pemerintah Kabupaten Klungkung untuk memudahkan aparatur dalam menginput kegiatan dan membuat laporan kerja harian. Pembuatan aplikasi ini diharapkan mampu menjadi pemacu para aparatur untuk meningkatkan kinerjanya serta menjadi salah satu pendukung bagi pimpinan dalam mengambil keputusan terkait dengan kinerja pegawai, unit kerja dan satuan kerja

\section{Daftar Aktivitas Dalam E-Kinerja}

Dalam aplikasi E-Kinerja Kabupaten Klungkung terdapat daftar aktivitas yang dapat dilaporkan oleh pegawai. Aktivitas dibedakan berdasarkan jabatan dan tupoksi masing-masing pegawai. Setiap aktivitas memiliki poin yang berbeda-beda. Aktivitas yang terdapat dalam E-Kinerja di bedakan menjadi dua (2) yaitu

1. Aktivitas Umum, yaitu aktivitas/kegiatan yang bisa dilakukan/dilaporkan oleh seluruh pegawai.

2. Aktivitas Teknis, yaitu aktivitas/kegiatan yang bisa dilakukan/ dilaporkan berdasarkan tupoksi masing-masing

\section{Hasil dan Pembahasan}




\section{Penerapan Elektronik kinerja (E-Kinerja) terhadap motivasi kerja pegawai di Kantor Camat Klungkung}

Tujuan penerapan E-Kinerja adalah untuk meningkatkan disiplin pegawai (ASN), meningkatkan kinerja pegawai, dan meningkatkan motivasi kerja pegawai. Penerapan E-Kinerja diharapkan dapat merekam semua aktvitas yang dikerjakan dan dilaporkan oleh pegawai/ASN, mengukur kinerja pegawai, sebagai bahan evaluasi kinerja pegawai dan bahan pembinaan pegawai. E-Kinerja juga sebagai salah satu instrument pemberian tambahan penghasilan bagi pegawai/ASN sesuai dengan aktivitas yang dikerjakan.

Mengacu kepada teori Harapan menurut Victor Vroom yang dihubungkan dengan fenomena Penerapan E-Kinerja dinyatakan bahwa kekuatan yang memotivasi seseorang untuk bekerja tergantung dari hubungan timbal balik antara yang diinginkan dan dibutuhkan dari hasil pekerjaan itu. Premis teori ini didasarkan atas tiga unsur yang menjadi konsep kunci yaitu: Harapan, Instrumentality dan Valensi.

\section{Harapan (Expectancy).}

Harapan merupakan kepercayaan seseorang bahwa suatu usaha akan menghasilkan kinerja tertentu. Effort (Usaha) $\rightarrow$ Performance (Kinerja). Berdasarkan hasil wawancara yang dilakukan dengan sejumlah informan di Kantor Camat Klungkung diperoleh hasil bahwa sejak diterapkannya sisten E-Kinerja, motivasi pegawai dalam bekerja menunjukkan kecendrungan semakin meningkat.

Sejak E-Kinerja diterapkan, terjadi peningkatan realisasi kegiatan. Pada Tahun 2018 realisasi kegiatan sebesar 95,41\%, dan pada Tahun 2019 meningkat sebesar 2,75\% menjadi 98,16\%. Hal ini menunjukkan bahwa E-Kinerja memberikan pengaruh terhadap peningkatan motivasi kerja pegawai di Kantor Camat Klungkung. Hal ini sesuai dengan yang dinyatakan dalam teori harapan (Expectancy) yaitu kepercayaan seseorang bahwa suatu usaha akan menghasilkan kinerja tertentu.

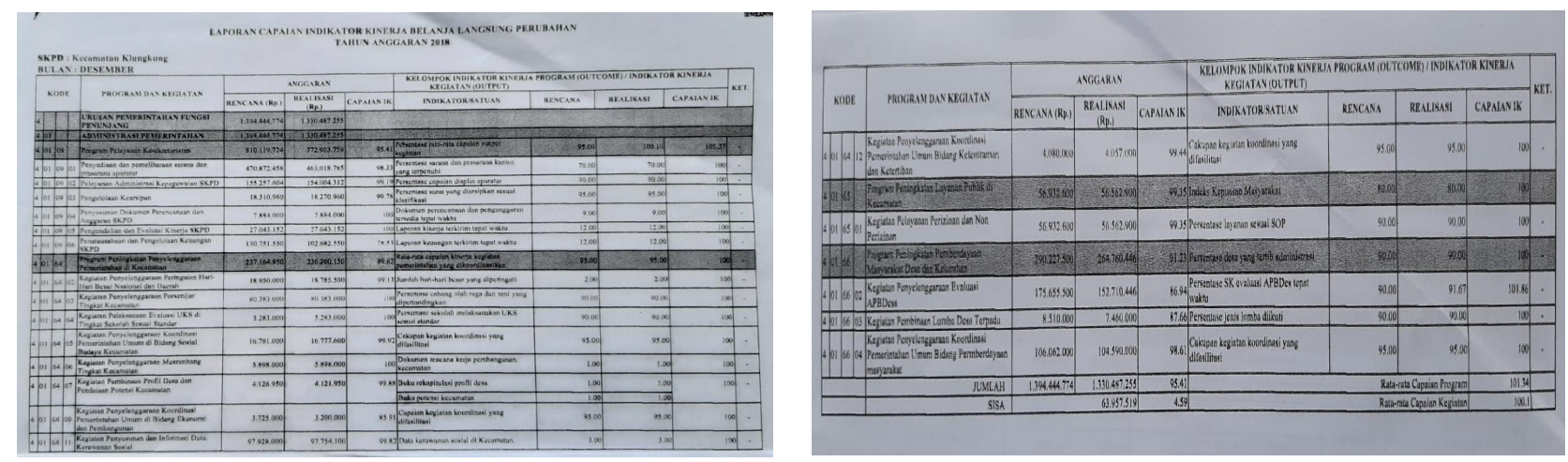

\section{Gambar 1}

Daftar Realisasi Kegiatan Tahun 2018

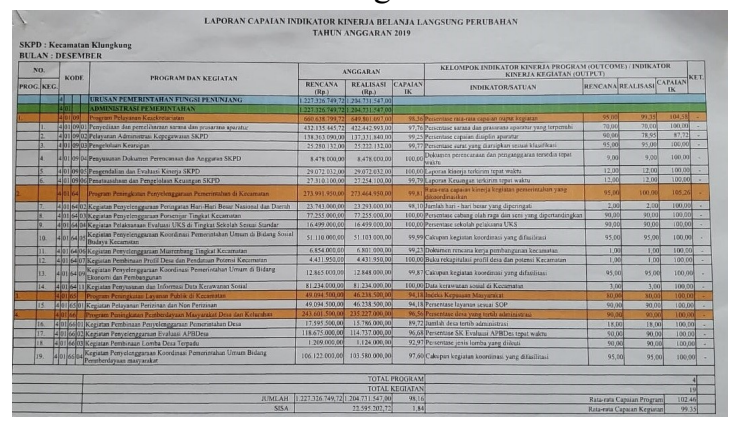

Gambar 2

Daftar Realisasi Kegiatan Tahun 2019 
Instrumentality

Instrumentality dimaksudkan adalah kepercayaan seseorang bahwa suatu kinerja akan mendapatkan hasil tertentu. Secara skematis dirumuskan dengan tanda. Performance (Kinerja) $\rightarrow$ Outcome (Hasil). Sejak diberlakukannya E-Kinerja, pemberian Tunjangan Kinerja Daerah (TKD) kepada pegawai dibagi atas 2 komponen yaitu:

a. Tunjangan Statis yaitu tunjangan yang diberikan berdasarkan pada nilai jabatan yang dihasilkan melalui proses evaluasi jabatan. (Pasal 4 ayat 1 Perbup Klungkung Nomor 2 Tahun 2019)

b. Tunjangan Dinamis yaitu tunjangan yang diberikan berdasarkan pada aktifitas yang dilaporkan oleh masing-masing pegawai pada aplikasi E-Kinerja. Pasal 5 ayat 1 Perbup Klungkung Nomor 2 Tahun 2019)

Dari hasil wawancara kepada pegawai Kantor Camat Klungkung tampak jelas bahwa dengan berlakunya E-Kinerja memberikan dampak yang besar terhadap perbaikan kinerja pegawai di Kantor Camat Klungkung. Hal ini tentunya tidak lepas dari keyakinan para pegawai untuk mendapatkan poin maksimal guna memperoleh TKD yang maksimal.

Peningkatan jumlah TKD yang diterima pegawai pada Kantor Camat Klungkung dari tahun 2018 dibanding tahun 2019 dapat lihat dari gambar berikut

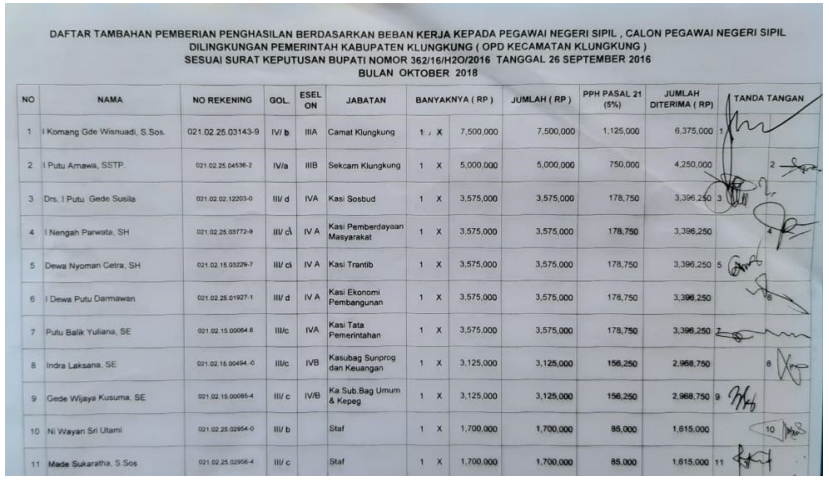

Gambar 3

Besaran Tunjangan Beban Kerja Tahun 2018

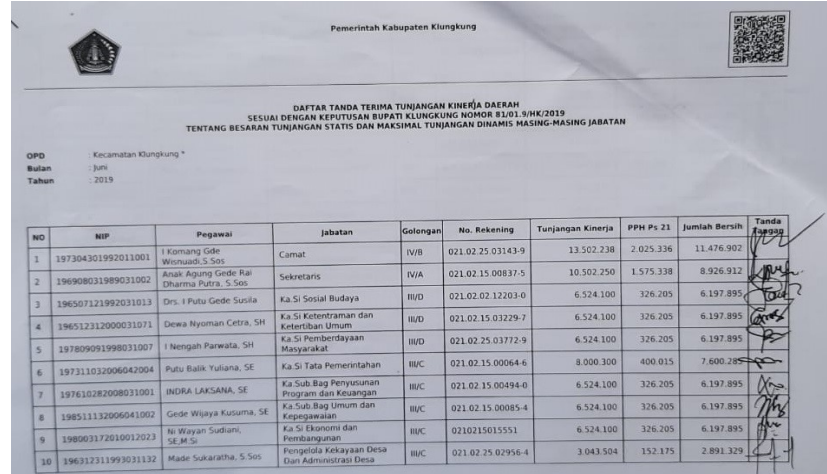

Gambar 4

Besaran TKD Tahun 2019

\section{Valensi}

Valensi dimaknai sebagai akibat dari perilaku tertentu mempunyai nilai / martabat tertentu (daya/nilai motivasi) bagi setiap individu yang bersangkutan. E-Kinerja juga digunakan sebagai salah satu acuan dalam mengukur kinerja pegawai, sebagai bahan evaluasi kinerja pegawai, dan bahan pembinaan pegawai berdasarkan pada perjanjian kinerja yang telah dibuat setiap awal tahun

Dalam E-Kinerja terdapat laporan mengenai total poin akumulatif yang telah diperoleh, capaian rencana aksi kegiatan, capaian kedisiplinan serta akumulasi besaran tunjangan yang diterima. Setiap pekerjaan yang dilaporkan dalam E-Kinerja secara otomatis akan mempengaruhi nilai dan besaran capain tersebut, hal ini berdampak juga kepada penilaian kinerja seorang pegawai.

Hasil penelitian menunjukkan bahwa Pemberlakuan E-Kinerja telah mampu memotivasi semangat kerja pegawai di Kantor Camat Klungkung, sebab E-Kinerja secara otomatis merekam dan menilai capaian rencana aksi pegawai. Kenyatan ini tentu memiliki akibat terhadap penilaian kinerja pegawai yang bersangkutan. 'Rapor' atau jejak digital pada E-kinerja tersebut dapat dijadikan sebagai salah satu bahan pertimbangan dalam peningkatan karier seorang pegawai.

Setiap pegawai berharap bahwa dengan berlakunya E-Kinerja akan memberikan penilaian 
kepada pegawai secara obyektif berdasarkan kepada capaian rencana aksi kegiatan, sehingga timbul semangat berkompetisi di antara pegawai untuk memperoleh poin maksimal guna meningkatkan jenjang karier/jabatannya.

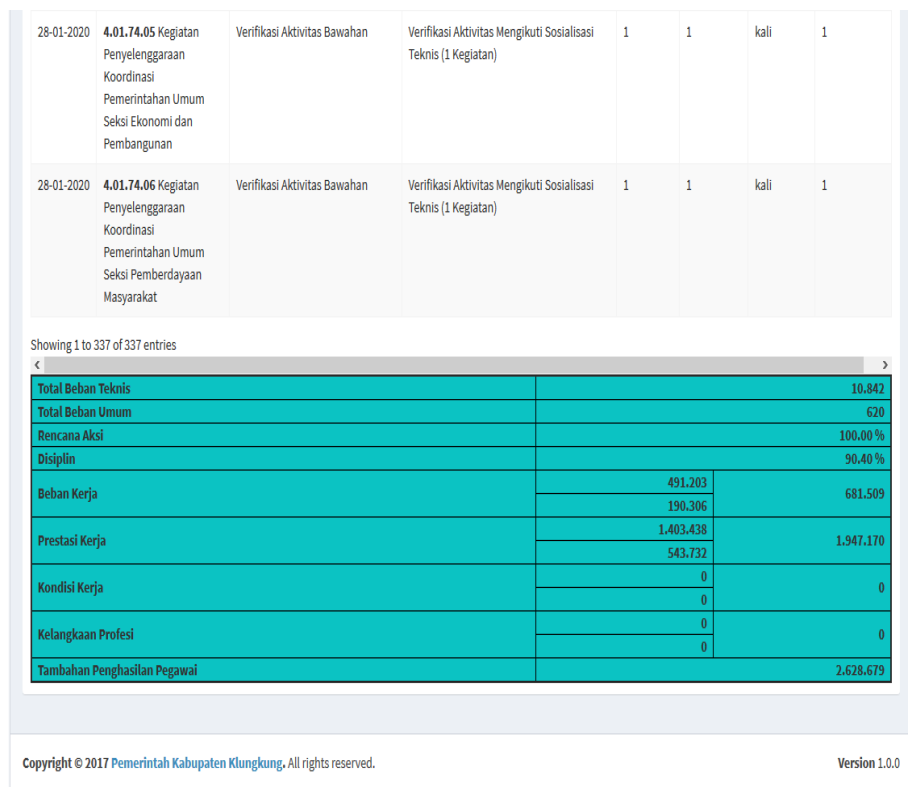

Gambar 5

Tampilan E-Kinerja Tahun 2020

Faktor Pendukung dan Faktor Penghambat Penerapan E-Kinerja di Kantor Camat Klungkung

Faktor Pendukung

Mengacu Teori model implementasi kebijakan dari Van Meter dan Van Horn menjelaskan bahwa kinerja kebijakan dipengaruhi oleh beberapa variabel yang saling berkaitan, yaitu standar dan sasaran kebijakan, sumber daya, karakteristik organisasi pelaksana, komunikasi antar organisasi, disposisi atau sikap para pelaksana dan lingkungan sosial, politik, dan ekonomi

\section{a. Standar dan sasaran kebijakan}

Untuk mengukur kinerja implementasi kebijakan tentunya diperlukan standar dan sasaran kebijakan, yang pada dasarnya menyangkut tentang hal-hal yang hendak dicapai oleh sebuah kebijakan, baik jangka pendek, menengah atau panjang. Kejelasan dan sasaran kebijakan harus dapat diukur secara spesifik sehingga kesuksesan dan kegagalan kebijakan dapat diketahui.

Dari hasil penelitian ditemukan bahwa Standar dan sasaran kebijakan merupakan faktor pendukung penerapan E-Kinerja. Standar dan sasaran yang jelas menghindari terjadinya multi interpretasi, menghindari terjadinya kesalahpahaman, dan konflik di antara para agen implementasi. Penerapan E-Kinerja di Kantor Camat Klungkung berdasarkan pada Peraturan Bupati Klungkung No 2 Tahun 2019 telah memuat standar pelaksanaan/pelaporan E-Kinerja. Sasaran dari E-Kinerja adalah untuk meningkatkan kesejahteraan umum pegawai dan untuk meningkatkan motivasi kerja pegawai dalam rangka meningkatkan kinerja dan mutu pelayanan pemerintah.

\section{b. Sumber daya}

Keberhasilan implementasi kebijakan sangat tergantung dari kemampuan memanfaatkan sumber daya yang tersedia baik itu sumber daya manusia, sumber daya anggaran maupun sumber daya peralatan. Dari hasil penelitian diketahui bahwa Sumber daya manusia (SDM) sebagai agen pelaksana implementasi yang ada di Kantor Camat Klungkung telah memadai. SDM yang dimiliki telah 
memiliki ketrampilan, berkat pelatihan dan sosialisasi E-Kinerja yang intens dilaksanakan sebelum $E$ Kinerja ini diterapkan. Kenyataan ini mampu menjadi faktor pendukung penerapan E-Kinerja di Kantor Camat Klungkung.

Selain sumber daya manusi, sumber daya anggran juga memegang peranan penting. Guna mendukung penerapan E-Kinerja, Kantor Camat Klungkung mengalokasikan anggaran yang cukup besar. Selain sumber daya manusia dan sumber daya dana/anggaran, sumber daya peralatan juga menjadi faktor pendukung keberhasilan penerapan implementasi kebijakan. Guna mendukung penerapan E-Kinerja, Pemerintah Kabupaten Klungkung telah mempersiapkan aplikasi dan situs web sebagai sarana pendukung penerapan E-Kinerja.

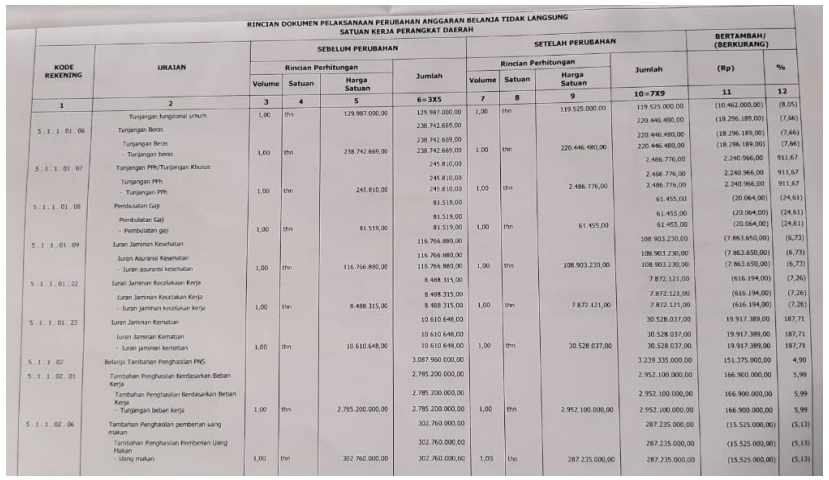

Gambar 6

Alokasi anggaran tunjangan beban kerja Tahun 2018

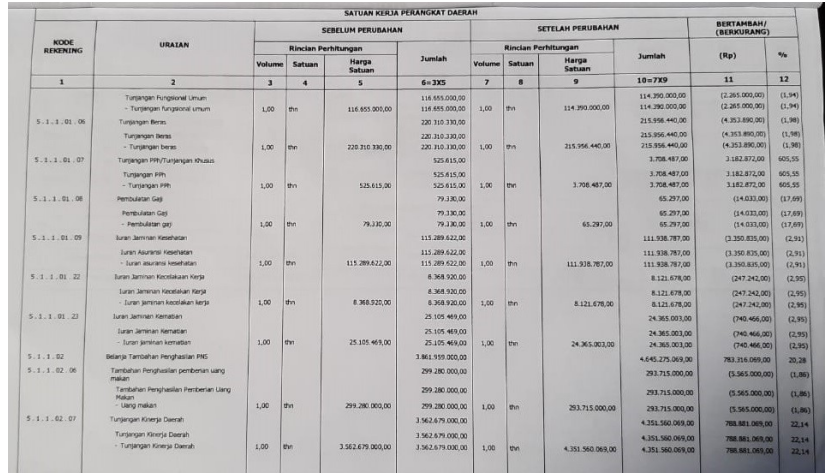

Gambar 7

Alokasi anggaran Tunjangan Kinerja Daerah Tahun

\section{c. Karakteristik organisasi pelaksana}

Van Meter dan Van Horn dalam Winarno (2007:163) mengungkapkan bahwa karakteristik agen pelaksana adalah mencakup struktur birokrasi, norma-norma, dan pola-pola hubungan yang terjadi dalam birokrasi. Sikap para pelaksana dalam menjalankan tugas dan tanggung jawab sebagai pelaksana kebijakan harus dilandasi dengan sikap disiplin. Hal tersebut dilakukan karena dapat mempengaruhi keberhasilan implementasi kebijakan. Setiap badan/instansi pelaksana kebijakan harus memiliki tanggung jawab terhadap tugasnya masing-masing berdasarkan rencana yang telah ditetapkan sebelumnya

Keberhasilan implementasi kebijakan sangat dipengaruhi oleh ciri yang tepat serta cocok dengan para pelaksananya. Pada beberapa kebijakan dituntut pelaksana kebijakan yang ketat dan disiplin, pada kebijakan lain diperlukan pelaksana kebijakan yang demokratis dan persuasive. Dalam penerapan E-Kinerja, setiap pegawai membuat laporan kegiatan yang nantinya akan diverifikasi oleh atasannya.

Dari hasil analisis yang dilakukan, dapat dikatakan bahwa karakteristik agen pelaksana, dalam hal ini pegawai di Kantor Camat Klungkung mendukung penerapan E-Kinerja. Masing-masing pegawai memegang dan melaksanakan fungsinya masing-masing dalam penerapan E-Kinerja

\section{d. Komunikasi antar organisasi}

Agar kebijakan publik bisa dilaksanakan dengan efektif, menurut Van Horn dan Van Mater bahwa, yang menjadi standar tujuan harus dipahami oleh para individu (implementors) terutama yang bertanggung jawab atas pencapaian standar dan tujuan kebijakan. Karena itu, standar dan tujuan harus dikomunikasikan kepada para pelaksana. Komunikasi dalam kerangka penyampaian informasi kepada para pelaksana kebijakan tentang apa menjadi standar dan tujuan harus konsisten dan seragam (consistency and uniformity) dari berbagai sumber informasi. Jika tidak ada kejelasan dan konsistensi serta keseragaman terhadap suatu standar dan tujuan kebijakan, maka yang menjadi 
Public Inspiration: Jurnal Administrasi Publik, 6 (1) (2021), 63

Penerapan Elektronik Kinerja (E-Kinerja) terhadap Motivasi Kerja Pegawai di Kantor Camat Klungkung

standar dan tujuan kebijakan sulit untuk bisa dicapai. Dengan kejelasan itu, para pelaksana kebijakan dapat mengetahui apa yang diharapkan darinya dan tahu apa yang harus dilakukan

Terkait E-Kinerja terjalin komunikasi antara Bagian Organisasi Sekretariat Daerah Kabupaten Klungkung yang dalam hal ini bertindak sebagai operator dengan Organisasi Perangkat Daerah (OPD), yang salah satunya adalah Kantor Camat Klungkung dalam penerapan E-Kinerja. Setiap permasalahan yang muncul akan segera dilaporkan kepada Bagian Organisasi untuk segera mendapat penanganan. Dengan koordinasi yang baik antara Bagian Organisasi dengan Kantor Camat Klungkung, pelaksanaan E-Kinerja berjalan dengan baik sehingga menjadi salah satu faktor pendukung keberhasilan penerapan E-Kinerja di Kantor Camat Klungkung

\section{e. Disposisi atau sikap para pelaksana}

Menurut pendapat Van Metter dan Van Horn (dalam Agustinus, 2006) bahwa: "sikap penerimaan atau penolakan dari agen pelaksana kebijakan sangat mempengaruhi keberhasilan atau kegagalan implementasi kebijakan publik. Hal ini sangat mungkin terjadi karena kebijakan yang dilaksanakan bukanlah hasil formulasi warga setempat yang mengenal dengan baik permasalahan dan persoalan yang mereka rasakan. Tetapi kebijakan publik cenderung bersifat dari atas ke bawah (top down) yang sangat mungkin para pengambil keputusan tidak mengetahui bahkan tak mampu menyentuh kebutuhan, keinginan atau permasalahan yang harus diselesaikan".

Sebagai sebuah kebijakan yang lahir dari sebuah keputusan oleh pemimpin tertinggi di Kabupaten Klungkung (Bupati) yang wajib dilaksanakan oleh seluruh pegawai di Kabupaten Klungkung, sehingga Disposisi atau sikap para pelaksana ini menjadi faktor pendukung keberhasilan penerapan E-Kinerja di Kantor Camat Klungkung.

\section{Faktor Penghambat}

\section{a. Lingkungan sosial}

Lingkungan sosial yang tidak kondusif dapat menjadi sumber masalah dari kegagalan kinerja implementasi kebijakan. Karena itu, upaya implementasi kebijakan mensyaratkan kondisi lingkungan sosial yang kondusif. Dari hasil wawancara dan observasi dilapangan diketahui bahwa Faktor Lingkungan Sosial menjadi faktor penghambat penerapan E-Kinerja di Kantor Camat Klungkung, yaitu adanya pandangan negatife masyarakat terhadap pegawai yang berswafoto untuk kepentingan sebagai salah satu bukti kegiatan.

\section{b. Politik}

Peraturan Bupati Klungkung Nomor 2 Tahun 2019 sebagai dasar penerapan E-Kinerja merupakan kebijakan publik yang bersifat top down, di mana dalam perumusan keputusan tersebut, khususnya dalam penentuan daftar aktifitas/kegiatan yang bisa dilaporkan tidak melalui proses survey terlebih dahulu sehingga banyak kegiatan yang tidak ada dalam daftar kegiatan, namun faktanya kegiatan tersebut ada dilaksanakan. Sehingga factor politik menjadi salah satu penghambat dalam penerapan E-Kinerja di Kantor Camat Klungkung.

\section{c. Ekonomi}

Sebagai sebuah sistem yang berbasis teknologi informasi, E-Kinerja dapat diakses menggunakan perangkat keras (PC atau laptop) maupun menggunakan smartphone. Umumnya pembuatan laporan dalam E-Kinerja dilakukan menggunakan smartphone karena lebih praktis dan mudah dibawa. Dari hasil pengamatan dan wawancara yang dilakukan, dapat disimpulkan bahwa faktor ekonomi menjadi salah satu faktor penghambat dalam penerapan E-Kinerja di Kantor Camat Klungkung karena setiap pegawai secara tidak langsung diwajibkan untuk memiliki sebuah smartphone dilengkapi dengan paket data yang setiap saat harus siap, sebab jika hanya mengandalkan sarana hotspot/wifi kantor sering mengalami gangguan. 


\section{Simpulan}

Berdasarkan uraian pada bab-bab sebelumnya, dapat ditarik kesimpulan yaitu; Penerapan Elektronik Kinerja (E-Kinerja) mampu meningkatkan motivasi kerja pegawai di Kantor Camat Klungkung. Terdapat sejumlah faktor pendukung dan penghambat dalam Penerapan E-Kinerja di Kantor Camat Klungkung, yaitu :

a. Faktor pendukung, yaitu faktor internal yang terdiri dari :

* Standar dan sasaran kebijakan yang jelas.

* Sumber daya, meliputi SDM, dana, dan peralatan yang memadai.

* Karakteristik organisasi pelaksana.

* Komunikasi Antar Organisasi yang berjalan lancer.

* Disposisi atau sikap para pelaksana yang taat aturan.

b. Faktor penghambat, yaitu faktor eksternal yang terdiri dari

* Faktor lingkungan sosial

* Politik

* Kondisi ekonomi pelaksana.

\section{Daftar Pustaka}

Agustino, L. (2008) . Dasar-Dasar Kebijakan Publik. Bandung: Cv.Alfabeta.

Hanifah, Y. (2017). Pengaruh Tunjangan Kinerja Terhadap Motivasi Kerja, Disiplin Kerja Dan Kinerja Pegawai Balai Pengelolaan Daerah Aliran Sungai Di Jawa Timur. BISMA: Jurnal Bisnis Dan Manajemen, 11(2), 187 - 193. doi:10.19184/bisma.v11i2.6313

Hardani, L., Bachri, A. A., \& Dahniar. (2016). Pengaruh Tunjangan Kinerja Dan Disiplin Kerja Terhadap Kinerja Pegawai Negeri Sipil Balai Karantina Pertanian Kelas I Banjarmasin. Jurnal Wawasan Manajemen Universitas Lambung Mangkurat

Instruksi Presiden No. 3 Tahun 2003 tentang Kebijakan Dan Strategi Nasional Pengembangan E Government

Mahendra. (2016). Efektivitas Pemberian Tunjangan Kinerja Daerah ( Studi Pada Biro Perlengkapan Dan Aset Daerah Provinsi Lampung). Jurnal Universitas Lampung

Mangkunegara, A. P. (2011). Manajemen Sumber Daya Manusia. Bandung: PT. Remaja Rosdakarya

Mudlika, N. (2015). Pengaruh Tunjangan Kinerja Daerah Dan Budaya Organisasi Terhadap Disiplin Pegawai Pada Biro Umum Setda Provinsi Lampung. Jurnal Universitas Lampung

Peraturan Pemerintah Nomor 105 Tahun 2000 tentang pengelolaan dan pertanggung jawaban keuangan daerah

Peraturan Pemerintah NO 11 Tahun 2017 Tentang Manajemen Pegawai Negeri Sipil

Peraturan Presiden (PerPres) No. 95 Tahun 2018 tentang sistem pemerintahan berbasis elektronik

Permendagri No. 59 Tahun 2007 tentang perubahan atas Permendagri No 13 Tahun 2006 tentang pedoman pengelolaan keuangan daerah

Peraturan Menteri Pemberdayaan Aparatur Negara dan Reformasi Birokrasi Nomor 63 tahun 2011 Tentang Pedoman Penataan Sistem Tunjangan Kinerja Pegawai Negari

Peraturan Bupati Klungkung Nomor 35 Tahun 2016 
Public Inspiration: Jurnal Administrasi Publik, 6 (1) (2021), 65

Penerapan Elektronik Kinerja (E-Kinerja) terhadap Motivasi Kerja Pegawai di Kantor Camat Klungkung

Peraturan Bupati Klungkung No334/23/HK/2018 tentang Perubahan Ketiga Atas Keputusan Bupati Klungkung Nomor 362/16/H2O/2016 Tentang Pemberian Tambahan Penghasilan Berdasarkan Beban Kerja Kepada Pegawai Negeri Sipil Dan Calon Pegawai Negeri Sipil Lingkup Pemerintah Daerah Kabupaten Klungkung.

Peraturan Bupati Klungkung Nomor 2 Tahun 2019 Tentang Pemberian Tunjangan Kinerja Daerah Kepada Pegawai Negeri Sipil Dan Calon Pegawai Negeri Sipil

Putri, G. D. (2016). Evaluasi Pelaksanaan Pemberian Tunjangan Kinerja Daerah (Tkd) (Studi Di Biro Humas Dan Protokol Setda Provinsi Lampung), Jurnal Universitas Lampung

Saleh, S., \& Darwis, M. (2015). Pengaruh Tunjangan Kinerja Terhadap Kinerja Pegawai Pada Bauk Universitas Negeri Makassar. Jurnal Ilmu A dministrasi publik

Sastrohadiwiryo, B. S. (2005). Manajemen Tenaga Kerja Indonesia Pendekatan Administratif Dan Operasional. Jakarta: PT. Bumi Aksara.

Undang-Undang No. 5 Tahun 2014 Tentang Aparatur Sipil Negara (ASN)

Usmiar. (2016). Pengaruh Tunjangan Kinerja Terhadap Motivasi Kerja Anggota Polri Dan Pegawai Negeri Sipil Polri Di Lingkungan Negara Republik Indonesia, Studi Kasus Polres Payakumbuh, E-Jurnal Menara Ilmu

Van Meter, D., \& Van Horn, C. E. (1975). The Policy Implementation Process Conseptual Frame Work, Journal Administration and Society.

Winarno, B. (2014). Kebijakan Publik Teori,Prosesdan Studi Kasus, Cetakan Kedua, Yogyakarta. Caps.

Wuaten, T. W. B. (2013). Implementasi Kebijkan Tunjangan Kinerja Daerah Di Badan Pelayanan Perizinan Terpadu Kota Manado. JURNAL ILMU ADMINISTRA SI (JIA) 